\title{
PERANCANGAN DAN PEMBUATAN \\ CHARGER HANDPHONE PORTABLE MENGGUNAKAN \\ SISTEM PENGGERAK GENERATOR AC DENGAN PENYEARAH
}

\author{
DESIGN AND DEVELOPMENT PORTABLE CHARGER HANDPHONE USING \\ DRIVER SYSTEM GENERATOR AC WITH RECTIFIER
}

${ }^{1}$ Arief Hendra Saptadi, ${ }^{2}$ Jaenal Arifin, ${ }^{3}$ Wasis Dasa Nugraha

${ }^{1,2,3}$ Program Studi D-III Teknik Telekomunikasi

Akademi Teknik Telekomunikasi Sandhy Putra Purwokerto

${ }^{1}$ Ariefhs2002@yahoo.com, ${ }^{2}$ jaetoga@yahoo.com, ${ }^{3}$ dwasis@yahoo.com

\begin{abstract}
ABSTRAKSI
Catu daya dalam sebuah sistem merupakan bagian yang utama, karena sebagai sumber atau penyedia energi, begitu pula pada perangkat telekomunikasi yang digunakan seperti handphone. Catu daya pada handphone adalah baterai, apabila suatu saat baterai dalam keadaan lowbatt, dan tidak ada sumber catuan listrik yang dapat digunakan tentunya hal tersebut dapat mengganggu proses komunikasi yang akan dilakukan. Perancangan perangkat ini dibagi menjadi beberapa blok rangkaian, yaitu blok catu daya yang berisi sumber sebagai penyedia energi (generator AC), rangkaian penyearah, filter, dan blok Pulsa width modulator $(P W M)$, serta blok rangkaian penguat arus.

Ketika generator AC diputar, maka otomatis akan menghasilkan tegangan bolak-balik, yang nantinya akan disearahkan menjadi tegangan DC oleh penyearah. Outputan tegangan DC tersebut akan diperkecil tegangan ripplenya dengan filter, kemudian akan distabilkan dengan regulator zener 5,6 V. Dari regulator, tegangan yang telah stabil masuk pada IC 555 sebagai timer dan Pulsa width modulator sebagai pengontrol frekuensi. Output IC 555 akan diteruskan ke penguat arus sehingga output dari rangkaian sesuai dengan spsesifikasi baterai handphone.

Hasil dari perancangan alat ini diharapkan dapat melakukan charging handphone pada saat lowbatt dan tidak ada catuan listrik lingkungan sekitar.
\end{abstract}

Kata kunci: Generator AC, Catu daya, PWM, Handphone

\section{ABSTRACT}

Power Supply in a system is a main part, because of its role as an energy source. This also applied in telecommunication equipment, such as handphone. The main power supply in a handphone is the battery. Consequently, if the battery is low and there is no electricity around, this will disrupt the ongoing communication process. Design of the equipment is divided into certain circuit blocks, i.e. power supply which is used as an energy source (in the form of AC generator), rectifier, filter and Pulsa width modulator $(P W M)$, and current amplifier.

When the AC generator is rotated, it will supply alternating voltage which in turn, this voltage would be converted into DC Voltage by rectifier. The ripple voltage component on this DC Voltage would be minimized by filter and stabilized by $5.6 \mathrm{~V}$ Zener regulator. From this regulator, the stabilized voltage will go to the input pin on IC 555 (or simply, 555) as a timer, and control the frekuensi via PWM circuit. The output of 555 would pass on to current amplifier in a way that this would meet the specification of handphone battery.

The result of the design is expected to be able to charge the handphone in a low battery condition when there is no electricity in the vicinity.

Keyword: Generator AC, Power Supply, PWM, Handphone 


\section{PENDAHULUAN}

\subsection{Latar Belakang}

Teknologi telekomunikasi saat ini telah berkembang sangat pesat. Hal tersebut dapat dilihat dengan munculnya alat-alat telekomunikasi yang semakin canggih, teknologi yang digunakan dalam telekomunikasi itu sendiri, serta penerapannya pada masyarakat luas. Salah satu alat komunikasi yang sudah umum digunakan pada jaman sekarang adalah handphone. Hampir setiap orang dilapisan masyarakat manapun, baik itu menengah ke bawah atau menengah ke atas, mempunyai handphone. Karena dengan menggunakan handphone, masyarakat bisa berkomunikasi secara langsung dalam bentuk voice atau sms dengan orang lain tanpa mengenal waktu, tempat dan kondisi.

Dengan dukungan teknologi yang ada, sekarang handphone pun berkembang baik dari sisi perangkatnya, seperti fasilitas infrared, bluetooth, maupun kabel USB untuk dapat melakukan transfer data. Maupun dari sisi penggunaannya yang dapat dimanfaatkan bukan hanya untuk sekedar voice atau sms, tetapi juga untuk komunikasi data seperti internet dan email yang menggunakan teknologi GPRS dan EDGE.

Untuk memperlancar komunikasi yang dilakukan, suatu alat komunikasi, dalam hal ini handphone haruslah mempunyai daya atau energi yang dapat bertahan cukup lama. Energi pada handphone disimpan pada sebuah baterai. Maka dari itu sebuah baterai handphone harus selalu menyimpan energi walaupun sedikit untuk memperlancar proses komunikasi. Tetapi ada kalanya baterai akan melemah atau Low Batt, sebagai contoh jika sedang dalam perjalanan jauh, tidak tersediannya catuan listrik seperti PLN, Genset, Car kit, tiba-tiba handphone mati karena low batt, padahal pada saat itu komunikasi sedang benar-benar dibutuhkan. Maka hal di atas dapat mengganggu proses komunikasi yang akan dilakukan.

\subsection{Perumusan Masalah}

a. Bagaimana blok diagram dan apa fungsi dari tiap-tiap blok diagram dari alat yang akan dibuat sebagai pencatu baterai handphone.

b. Bagaimana cara menentukan nilai dari tiap-tiap komponen yang akan digunakan agar output rangkaian sesuai dengan yang diinginkan

c. Bagaimana proses perancangan alat sampai bisa digunakan sebagai alat pencatu baterai handphone

1.3. Tujuan

a. Mengetahui blok diagram beserta fungsi dari setiap blok dari alat yang akan dibuat 
sebagai pencatu baterai handphone.

b. Dapat menentukan nilai masing-masing komponen penyusun alat sehingga alat bisa bekerja sesuai dengan yang diinginkan.

c. Dapat membuat alat pencatu daya baterai handphone portable dengan sistem penggerak Generator $\mathrm{AC}$ dengan penyearah.

1.4. Manfaat Penelitian

a. Alat ini dapat digunakan untuk mencatu handphone yang lowbatt (kehabisan energi), secara praktis karena tidak tergantung dengan sumber catuan lain seperti PLN, car kit atau genset.

1.5. Batasan Masalah

a. Tidak membahas sistem jaringan seluler secara detail.

b. Alat yang akan dibuat berkaitan dengan bagian catu daya baterai handphone

c. Alat ini tidak menggunakan media penyimpanan lain selain baterai handphone.

d. Alat ini digunakan pada saat yang darurat.

e. Alat ini digunakan untuk mencatu handphone Nokia 1208.

f. Alat ini dibuat untuk membuktikan bahwa apakah catu daya handphone menggunakan sistem penggerak Generator AC dengan penyearah bisa bekerja atau tidak, tanpa memperhitungkan umur pakai baterai HP.

1.6. Dasar Teori

a. Sistem Komunikasi Seluler

Komunikasi seluler saat ini benar-benar sudah menjadi kebutuhan pokok bagi masyarakat, terbukti dengan banyaknya penggunaan seluler. Disebut seluler karena area layanannya dibagi-bagi menjadi beberapa area kecil disebut cell, yang mempunyai karateristik pelanggan dapat bergerak bebas dalam area layanan dengan tetap berkomunikasi tanpa terjadi pemutusan hubungan.Mobile Station atau MS merupakan perangkat yang digunakan oleh pelanggan untuk melakukan pembicaraan, yang menggunakan sistem DTMF (Dual Tone Multi Frequency) dalam pengiriman datanya yaitu mengirimkan 2 buah frekuensi, frekuensi rendah dan frekuensi tinggi. MS sendiri terdiri atas: Mobile Equipment (ME) atau handset, merupakan perangkat yang berada di sisi pengguna atau pelanggan yang berfungsi sebagai terminal tranciever (pengirim dan penerima sinyal) untuk berkomunikasi dengan perangkat 
lainnya. Pada saat ini ME yang digunakan berupa sebuah handphone.

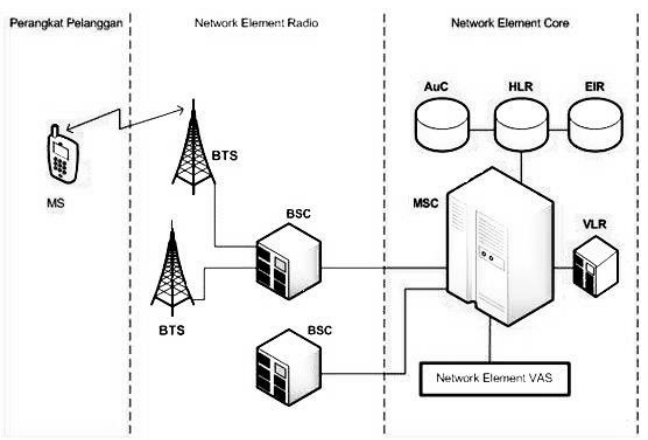

Gambar 1. Arsitektur Sistem Seluler

b. Baterai Handphone

Fungsi dari pada baterai adalah mengubah energi kimia menjadi energi listrik yang dapat digunakan sebagai sumber energi. Dibawah ini merupakan jenis-jenis baterai yang umumnya dipakai sebagai baterai handphone:

1) Nickel-Cadmium ( $\mathrm{NiCd}$ )

2) Nickel-Metal-Hydride(NiMH)

3) Lithium-Ion ( Li-Ion )

4) Lithium-Polymer (Li-Polymer)

c. Catu Daya

i) Generator $\mathrm{AC}$

Generator arus bolakbalik berfungsi mengubah tenaga mekanis menjadi tenaga listrik arus bolak-balik. Generator Arus Bolak-balik sering disebut juga sebagai alternator, generator AC (Alternating

Current).

Generator arus bolak-balik dibagi menjadi dua jenis, yaitu: Generator arus bolak- balik 1 fasa yaitu generator yang dimana dalam sistem melilitnya hanya terdiri dari satu kumpulan kumparan. ${ }^{[5]}$, dan generator arus bolak-balik 3 fasa yaitu generator yang dimana dalam sistem lilitanya terdiri dari tiga kumpulan kumparan yang mana kumparan tersebut masingmasing dinamakan lilitan fasa. [5]

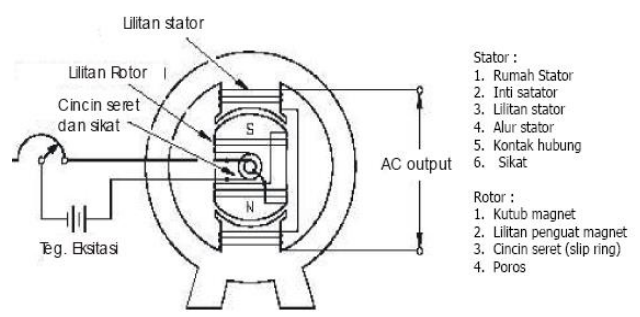

Gambar 2. Konstruksi generator AC. ${ }^{[5]}$

ii) Dioda

- Dioda penyearah

Dioda merupakan komponen elektronik yang terbuat dari bahan semikonduktor yang saling dipertemukan. Yaitu semikonduktor $\mathrm{P}$ dan semikonduktor N. Semikonduktor $\mathrm{P}$ (P type) merupakan semikonduktor yang terbuat dari campuran bahan silikon, germanium dan aluminium, mempunyai sifat kekurangan elektron sehingga disebut semikonduktor positif.

Sedangkan semikonduktor $\mathrm{N}$ merupakan semikonduktor yang terbuat dari campuran 
antara silikon, germanium dan fosfor yang memiliki kelebihan elektron sehingga disebut semikonduktor negatif. Dioda memiliki keunikan tersendiri, yaitu hanya dapat mengalirkan arus dalam satu arah saja, yaitu dari arah anoda (positif) ke arah katoda (negatif).

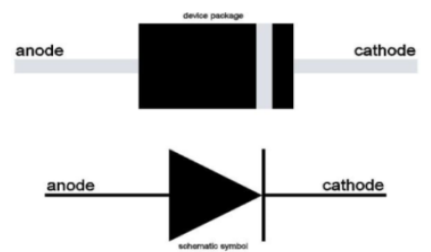

Gambar 3. Bentuk dan simbol dioda ${ }^{[4]}$

Dioda memiliki keunikan tersendiri, yaitu hanya dapat mengalirkan arus dalam satu arah saja, yaitu dari arah anoda (positif) ke arah katoda (negatif). Dioda Sebagai Penyearah (rectifier) digunakan untuk mengubah tegangan AC menjadi tegangan DC. Ada 2 jenis rectifier yang banyak digunakan dalam elektronika yaitu: Penyearah Setengah Gelombang dan Penyearah Gelombang Penuh

- Dioda Zener

Zener disini digunakan sebagai regulator tegangan. Dengan menggunakan zener dengan nilai 5,6 $\mathrm{V}$ maka outputan dari regulator tegangan akan sama dengan nilai zener tersebut. Nilai tersebut yang nantinya akan dimanfaatkan sebagai input tegangan referensi bagi rangkaian PWM dengan IC 555 sebagai komponen utamanya.

iii) Kapasitor sebagai Filter Tegangan keluaran dari suatu rangkaian penyearah pada umumnya akan menimbulkan tegangan ripple (misal: tegangan yang diinginkan keluar dari rangkaian penyearah adalah berupa tegangan DC murni, tetapi masih ada sedikit tegangan AC yang ikut terbawa, tegangan itulah yang dinamakan tegangan ripple) maka dibutuhkan sebuah komponen elektronika yang dipakai untuk mengecilkan atau bahkan menghilangkan tegangan tersebut karena dapat mempengaruhi keluaran dari charger yang dibuat.

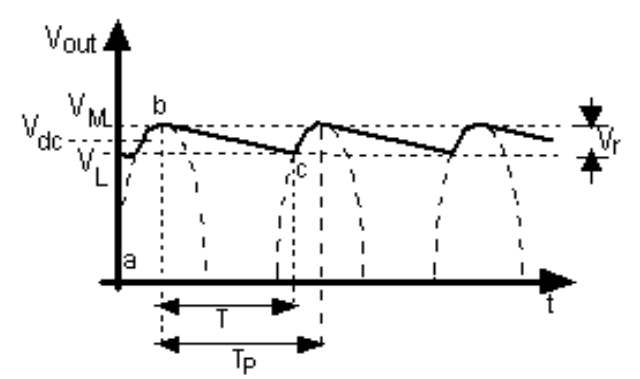

Gambar 4. gelombang dengan filter kapasitor 
d. IC 555

IC NE555 yang mempunyai 8 pin (kaki) ini merupakan salah satu komponen elektronika yang cukup terkenal, sederhana, dan serba guna dengan ukurannya yang kurang dari $1 / 2 \mathrm{~cm}^{3}$ (sentimeter kubik) ${ }^{[2]}$. Pada dasarnya aplikasi utama IC NE555 ini digunakan sebagai Timer (Pewaktu) dan Pulse Generator (Pembangkit Pulsa). Selain itu, dapat juga digunakan sebagai Time Delay Generator, Pulsa Width Modulator dan Sequential Timing.

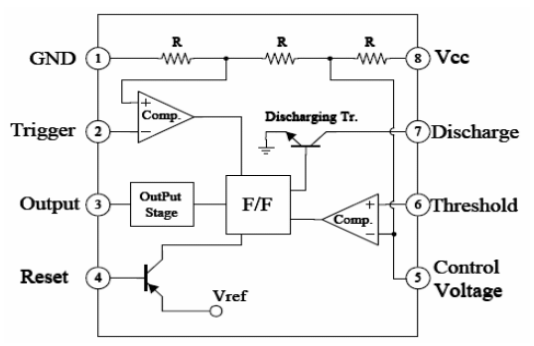

Gambar 6. Konfigurasi pin IC 555

Keterangan:

Pin 1 sebagai ground

Pin 2 sebagai trigger untuk men-set flip flop bila tegangan trigger-nya $<1 / 3$ Vcc.

Pin 3 sebagai output dari IC 555.

Pin 4 sebagai reset.

Pin 5 sebagai control voltage untuk pengatur tegangan ambang (threshold).

Pin 6 sebagai threshold berfungsi untuk mereset flip flop bila tegangan input pin melebihi $2 / 3$ vcc.

Pin 7 sebagai discharge yang merupakan jalur pembuangan arus.

Pin 8 sebagai VCC antara 5 V-15 V

e. Transistor

Pada umumnya, transistor memiliki 3 terminal yaitu basis (B), emitor (E), dan colektor (C), karena merupakan kombinasi 2 buah dioda (type $\mathrm{P}$ dan type $\mathrm{N}$ ) maka transistor dapat dibagi menjadi 2 macam, yaitu transistor PNP (Positive Negative Positive) dan NPN (Negative positive negative). Fungsi dari transistror pada bidang elektronika dapat berfungsi sebagai skalar otomatis, penguat baik itu penguat tegangan atau arus, dan sebagai regulator tegangan. Kelebihan transistor BD 139 adalah memiliki nilai $\mathrm{I}_{\mathrm{C}}$ dan gain yang cukup besar, yaitu sampai 1,5 A dan 250 kali. Dalam elektronika transistor disimbolkan sebagai berikut :

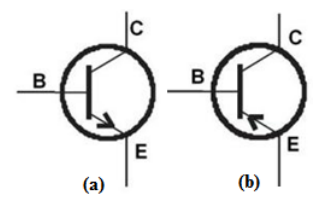

Gambar 7. (a) Transistor NPN dan (b) Transistor PNP 


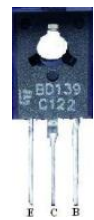

Gambar 8 . Bentuk Fisik Transistor Type BD 139

\section{METEDOLOGI PENELITIAN}

\subsection{Metode Eksperimental}

Metode ini bertujuan untuk mendapatkan rancangan alat yang akan dibuat dengan cara mencari, memodifikasi dan menguji rangkaianrangkaian elektronika untuk penelitian.

2.2. Metode Pengumpulan Data

Metode Pengumpulan Data

a) Data primer

Data yang didapatkan dari pengukuran secara langsung pada rangkaian.

b) Data sekunder

Data yang didapatkan dari referensi-referensi, datasheet atau perhitungan teori.

\subsection{Parameter yang Diamati}

Parameter yang diamati dalam penelitian ini meliputi :
a. Tegangan
b. Arus,
c. Putaran (Rpm)
d. Waktu

\subsection{Instrumen Penelitian}

Instrument penelitian yang digunakan adalah $P C$ yang dilengkapi dengan perangkat lunak elektronika yaitu Multisim 10.0 untuk simulasi rangkaian sebelum dibuat rangkaian sebenarnya dan
Protel PCB 1.5 untuk pembuatan rangkaian PCB.

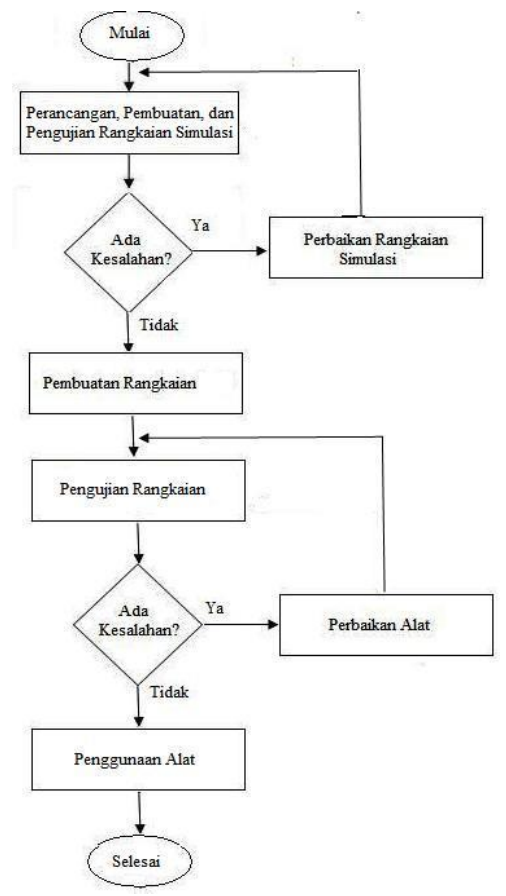

Gambar 9. Flowchart pengerjaan perangkat

\section{PERANCANGAN SISTEM}

a) Perancangan Sistem

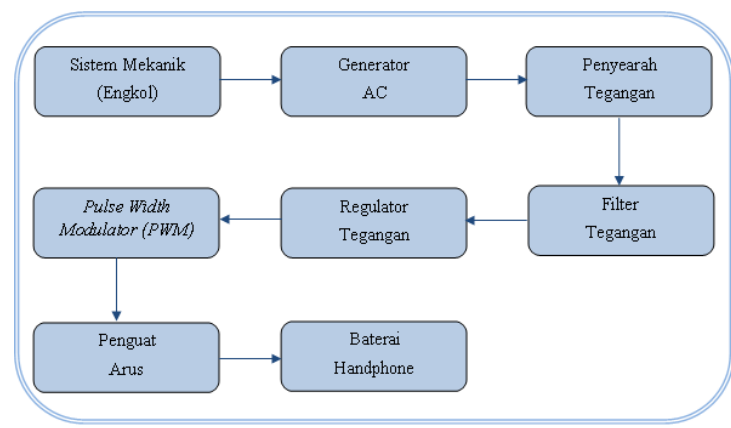

Gambar 10. Blok diagram perangkat

Keterangan:

1) Sistem Mekanik (Engkol)

Sistem mekanik disini adalah sebagai penggerak generator $\mathrm{AC}$ supaya menghasilkan listrik yang nantinya akan digunakan untuk dapat melakukan proses charging. Sistem mekanik ini berupa sebuah engkol yang digerakan secara manual dengan cara diputar. 


\section{2) Generator $\mathrm{AC}$}

Generator AC digunakan sebagai penghasil daya atau energi yang nantinya akan disalurkan ke baterai handphone melalui rangkaian elektronik yang akan dibuat.

3) Penyearah

Penyearah digunakan untuk menyearahkan tegangan AC menjadi tegangan DC.

4) Filter

Filter ini digunakan untuk menghilangkan rugi-rugi tegangan (tegangan ripple) yang keluar dari generator $\mathrm{AC}$ dengan penyearah yang digunakan sebelum masuk ke rangkaian charger.

5) Regulator Tegangan

Regulator digunakan untuk menstabilkan tegangan yang keluar dari rangkaian. Dengan tujuan mencegah rusaknya baterai handphone yang sedang diisi. Regulator yang digunakan adalah zener yang diseri dengan sebuah hambatan dengan nilai tertentu sehingga menghasilkan keluaran yang diinginkan.

6) Pulsa Width Modulator (PWM)

Pulsa Width Modulator (PWM) disini dibuat menggunakan IC 555 sebagai komponen utamanya, dengan mengatur lebar pulsa maka dapat ditentukan frekuensi serta tegangan output. Tentunya dengan tegangan referensi dari regulator dan penggunaan resitor variabel.
7) Penguat Arus

Digunakan untuk menguatkan arus yang keluar dari rangkaian sehingga dapat memenuhi spesifikasi dari baterai handphone yang dicharge. Penguat arus ini menggunakan transistor type BD 139.

8) Baterai HP

Baterai handphone ini digunakan sebagai beban.

b) Perangkat Keras

Tahapan pembuatan perangkat ini meliputi pemilihan, penentuan komponen dan pembuatan letak rangkaian pada papan PCB yang digunakan. Ada beberapa rangkaian yang digunakan pada penelitian ini, seperti rangkaian penyearah yang menggunakan dioda, rangkaian filter tegangan dengan kapasitor, rangkaian regulator tegangan menggunakan zener, Pulsa Width Modulator (PWM)yang menggunakan IC 555, serta penggunaan transistor sebagai penguat arus.

\section{PENGUJIAN DAN PEMBAHASAN}

\section{HASIL}

4.1. Pengujian Rangkaian

a. Pengujian Output Generator

Pengujian dilakukan dengan menggunakan multimeter sebagai alat ukurnya. Pengukuran ini dimaksudkan agar dapat diketahui output tegangan AC yang keluar dari generator AC dengan cara 
diputar secara manual. Tegangan output dari generator AC ini masih berbentuk tegangan bolakbalik sehingga nantinya perlu untuk disearahkan. Berikut adalah hasil pengukuran yang telah dilakukan:

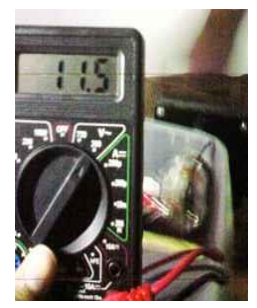

Gambar 11. Pengukuran output generator AC

Tabel 1. Perbandingan Output Tegangan

\begin{tabular}{|l|c|c|c|}
\hline $\begin{array}{c}\text { Variabel } \\
\text { Pengukuran }\end{array}$ & $\begin{array}{c}\text { Tegangan } \\
\text { Generator AC } \\
\text { (A) }\end{array}$ & $\begin{array}{c}\text { Hasil } \\
\text { Pengukuran } \\
(\mathbf{B})\end{array}$ & $\begin{array}{c}\text { Error } \\
(\boldsymbol{A}-\boldsymbol{B})\end{array}$ \\
\hline $\begin{array}{c}\text { Tegangan Output } \\
\text { Generator AC (V) }\end{array}$ & 12 & 11,5 & 0,5 \\
\hline
\end{tabular}

b. Pengujian Rangkaian Penyearah

Pengujian ini dilakukan karena sumber atau generator yang digunakan adalah AC (tegangan bolak-balik), sehingga perlu disearahkan sebelum masuk ke rangkaian supaya komponenkomponen yang telah dirangkai tidak mengalami kerusakan.

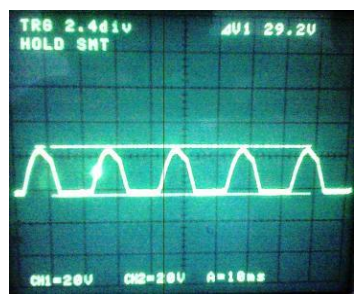

Gambar 12. Bentuk gelombang output penyearah

Gambar diatas merupakan output dari penyearah yang dibuat. Karena menggunakan penyearah gelombang penuh seharusnya gelombang yang dihasilkan merupakan gelombang penuh, tetapi yang terbaca pada osiloskop hanya setengah gelombang. Hal tersebut diakibatkan karena terbatasnya perangkat ukur osiloskop yang tidak bisa menampilkan bentuk gelombang penuh dengan sumber generator AC yang digunakan.

Tabel 2. Perbandingan Output Tegangan

\begin{tabular}{|c|c|c|c|}
\hline $\begin{array}{c}\text { Variabel } \\
\text { pengukuran }\end{array}$ & $\begin{array}{c}\text { Hasil } \\
\text { perhitungan } \\
\text { (A) }\end{array}$ & $\begin{array}{c}\text { Hasil } \\
\text { pengukuran } \\
(\mathbf{B})\end{array}$ & $\begin{array}{c}\text { Error } \\
(\boldsymbol{A}-\boldsymbol{B})\end{array}$ \\
\hline $\begin{array}{c}\text { Tegangan } \\
\text { Output } \\
\text { Penyearah (V) }\end{array}$ & 10,8 & 10,6 & 0,2 \\
\hline
\end{tabular}

c. Pengujian Filter

Tegangan DC yang keluar dari penyearah akan menghasilkan tegangan yang tak rata (ripple). Hal tersebut diakibatkan karena adanya sedikit kandungan tegangan AC yang masih tersisa. Untuk mengatasi masalah tersebut maka digunakan filter untuk memperkecil atau menghilangkan tegangan ripple tersebut. Berikut hasil pengukuran tegangan output dari rangkaian filter:

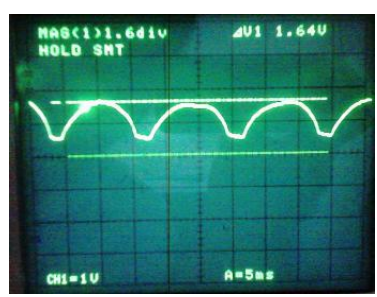

Gambar 13. Bentuk gelombang output filter

Pengujian diatas dilakukan dengan osiloskop. Output tersebut belum sesuai dengan yang diharapkan, karena seharusnya gelombang yang keluar adalah 
gelombang lurus yang menandakan bahwa tegangannya rata. Hal tersebut dikarenakan pemutaran generator AC yang kurang stabil.

Tabel 3. Perbandingan output filter

\begin{tabular}{|c|c|c|c|}
\hline $\begin{array}{c}\text { Variabel } \\
\text { pengukura } \\
\mathbf{n}\end{array}$ & $\begin{array}{c}\text { Hasil } \\
\text { perhitunga } \\
\mathbf{n}(\mathbf{A})\end{array}$ & $\begin{array}{c}\text { Hjasil } \\
\text { pengukura } \\
\mathbf{n}(\mathbf{B})\end{array}$ & $\begin{array}{c}\text { Erro } \\
\mathbf{r}(\boldsymbol{A}- \\
\boldsymbol{B})\end{array}$ \\
\hline $\begin{array}{c}\text { Tegangan } \\
\text { Output } \\
\text { Filter (V) }\end{array}$ & 16,95 & 12,56 & 4,39 \\
\hline
\end{tabular}

d. Pengujian Regulator Tegangan

Untuk dapat melakukan charging handphone diperlukan tegangan yang stabil, karena bila tak stabil dapat merusak komponen dalam handphone tersebut maupun baterai yang dicharge. Pengujian ini dimaksudkan untuk mendapatkan output yang sesuai dengan spesifikasi tegangan handphone pada umumnya, yaitu sekitar 3,5 V -6 V. Berikut adalah hasil pengukuran output regulator tegangan :

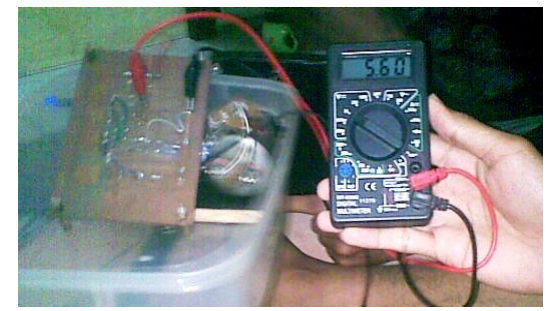

Gambar 14. Pengukuran regulator tegangan

Tabel.4. Perbandingan Output Tegangan

\begin{tabular}{|c|c|c|c|}
\hline $\begin{array}{c}\text { Variabel } \\
\text { pengukuran }\end{array}$ & $\begin{array}{c}\text { Hasil } \\
\text { perhitungan } \\
(\text { A) }\end{array}$ & $\begin{array}{c}\text { Hasil } \\
\text { pengukuran } \\
(\mathbf{B})\end{array}$ & $\begin{array}{c}\text { Err- } \\
\text { or } \\
(\mathbf{A}-\boldsymbol{B})\end{array}$ \\
\hline $\begin{array}{c}\text { Output } \\
\text { Regulator (V) }\end{array}$ & 5,6 & 5,6 & 0 \\
\hline
\end{tabular}

e. Pengujian Pulsa Width Modulator $(P W M)$
Pengujian ini dilakukan untuk menghasilkan gelombang kotak sesuai pada datasheet IC 555 yang digunakan, dan frekuensi yang sesuai dengan hasil perhitungan yang dilakukan. Berikut bentuk gelombang kotak yang dihasilkan dari rangkaian Pulsa Width Modulator (PWM):

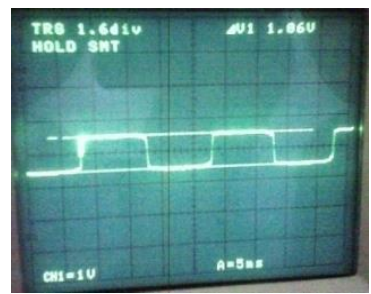

Gambar 15. Bentuk gelombang output $P W M$

Dari gelombang yang dihasilkan, dapat dilihat bahwa periode yang dihasilkan sekitar 1,9. Dari periode tersebut maka dapat dicari frekuensinya, yaitu:

$$
\begin{aligned}
& f=\frac{1}{T} \\
& f=\frac{1}{1,9} \\
& f=0,52 \mathrm{~Hz}
\end{aligned}
$$

Tabel 5. Perbandingan output PWM

\begin{tabular}{|c|c|c|c|}
\hline $\begin{array}{c}\text { Variabel } \\
\text { pengukuran }\end{array}$ & $\begin{array}{c}\text { Hasil } \\
\text { perhitungan } \\
(\mathbf{A})\end{array}$ & $\begin{array}{c}\text { Hasil } \\
\text { pengukuran } \\
(\mathbf{B})\end{array}$ & $\begin{array}{c}\text { Error } \\
(\boldsymbol{A}-\boldsymbol{B})\end{array}$ \\
\hline $\begin{array}{c}\text { Bentuk } \\
\text { Gelombang }\end{array}$ & Kotak & Kotak & - \\
\hline $\begin{array}{c}\text { Frekuensi } \\
(\mathrm{Hz})\end{array}$ & 0,51 & 0,52 & 0,01 \\
\hline
\end{tabular}

f. Pengujian Penguat Arus

Pengujian penguat arus ini dilakukan dengan cara mengukur arus basis, arus kolektor, arus emiter dan tegangan kolektor dengan menggunakan multimeter digital. Pada baterai handphone 
yang digunakan sebagai beban mempunyai spesifikasi arus sebesar $700 \mathrm{~mA} /$ hours, yang berarti baterai handphone memiliki batas arus pengisian maksimum sebesar $700 \mathrm{~mA}$ (kondisi fast charging) selama 1 jam.

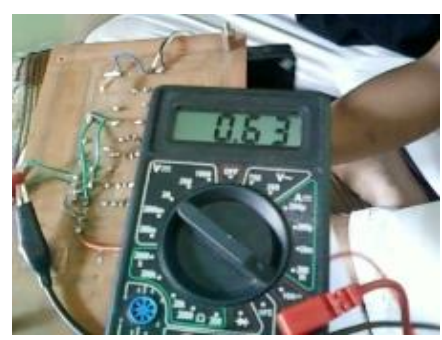

Gambar 16. Pengukuran arus kolektor

Tabel 6. Perbandingan Rangkaian Penguat

Arus

\begin{tabular}{|l|c|c|c|}
\hline \multicolumn{1}{|c|}{$\begin{array}{c}\text { Hariabel } \\
\text { Pengukuran }\end{array}$} & $\begin{array}{c}\text { Hasil } \\
\text { perhitungan } \\
\text { (A) }\end{array}$ & $\begin{array}{c}\text { pengukuran } \\
(\mathbf{B})\end{array}$ & $\begin{array}{c}\text { Error } \\
(\boldsymbol{A}-\boldsymbol{B})\end{array}$ \\
\hline $\mathrm{VCE}(\mathrm{V})$ & 0,45 & 0,43 & 0,02 \\
\hline $\mathrm{I}_{\mathrm{C}}(\mathrm{mA})$ & 700 & 630 & 70 \\
\hline $\mathrm{I}_{\mathrm{B}}(\mathrm{mA})$ & 0,28 & 0,22 & 0,06 \\
\hline
\end{tabular}

\subsection{Pembahasan Alat}

Dari hasil pengujian rangkaian secara keseluruhan, ada beberapa parameter yang diamati, yaitu:

a. Tegangan

Setelah dilakukan pengukuran output tegangan rangkaian keseluruhan, diperoleh nilai sebesar 3,7 V. Hal tersebut sudah sesuai dengan output yang diharapkan.

b. Arus

Arus total yang keluar dari rangkaian keseluruhan belum mencapai hasil yang diharapkan sebesar $700 \mathrm{~mA}$, yaitu sebesar 470 mA. Hal tersebut dikarena ketidakstabilan aliran arus yang masuk pada baterai, tetapi tidak menutup kemungkinan dapat mencapai 700 mA karena nilainya hampir sama dengan arus kolektor.

c. Putaran (Rpm)

Untuk dapat melakukan proses charging minimal generator harus berputar sebanyak 1173 putaran per menitnya. Lebih baik lagi jika melebihi putaran tersebut dan selalu stabil perpututarannya.

d. Waktu

Untuk dapat menghasilkan baterai dalam kondisi full, memerlukan waktu sekitar 3 jam Karena 1 batang indikator baterai diperoleh dengan memutar generator selama 30 menit, sedangkan pada handphone yang dipakai mempunyai 6 batang indikator.

\section{PENUTUP}

\subsection{Kesimpulan}

Dari perancangan perangkat yang sudah dibuat, maka dapat diambil beberapa kesimpulan, yaitu :

1. Kelebihan perangkat ini dibanding perangkat charger lain adalah dapat menghasilkan energi secara mandiri tanpa mengandalkan sumber catuan lain seperti PLN, 
genset atau car kit untuk melakukan proses charging.

2. Dalam perancangan perangkat ini dilakukukan dengan menggabungkan beberapa bagian rangkaian elektronika, yaitu Bagian mekanik, bagian catu daya yang berisi sumber, rangkaian penyerah, filter, rangkaian regulator, serta beberapa bagian lainya seperti pulsa width modulator, dan rangkaian penguat arus.

3. Dalam menentukan nilai komponen yang akan digunakan, dapat memakai persamaanpersamaan yang mendukung baik itu dari refrensi (buku dan internet) maupun datasheet berdasar output yang diharapkan dan sesuai dengan spesifikasi baterai handphone yang digunakan.

4. Pada rangkaian regulator tegangan yang dibuat menghasilkan error tegangan sebesar $0 \mathrm{~V}$, hal itu berarti regulator tegangan tersebut sudah sesuai dengan output yang diharapkan. Sedangkan arus regulator memiliki error sebesar 1,5 $\mathrm{mA}$, hal tersebut dapat disebabkan karena ketidakstabilan pemutaran generator yang dilakukan.

\subsection{Saran}

1. Membuat konstruksi engkol yang lebih sederhana dan efisien.
2. Untuk menghasilkan output arus yang diharapkan melakukan perhitungan ulang terhadap rangkaian penguat arus, baik untuk penggunaan resistor maupun transistor.

3. Untuk pengembangannya perangkat ini dapat dihubungkan dengan sesuatu yang pergerakannya stabil, continue, seperti dihubungkan dengan roda sepeda atau sepeda motor, pada kincir yang menggunakan tenaga angin atau air.

\section{DAFTAR PUSTAKA}

[1].Ahmad, Jayadin. 2007. ELDAS. Ilmu Elektronika. E-book. http://robby.c.staff.gunadarma.ac.i d/Downloads/files/8011/eldas.pdf (Di Akses pada Minggu, 6 Juni 2010 pukul 15.48 WIB)

[2]. Anynomous. 2009. Struktur, Fungsi, Cara Kerja Dasar Integrated Circuit (IC) NE5555. http://diary4share.blogspot.com/20 09/10/iptek-struktur-fungsiaplikasi-dan-cara.html (Di Akses pada Senin, 14 Juni 2010 pukul $12.23 \mathrm{WIB})$

[3]. Anynomous. 2008. Dioda Zener. http://elektronikaelektronika.blogspot.com/2008/02/ dioda-zener.html (Di Akses pada Senin, 14 Juni 2010, 8.34 WIB) [4].Anynomous. 2010. Prinsip Dioda Dioda, Zenner dan LED 
http://www.electroniclab.com/inde

x.php?option=com_content\&view

=article\&id=15:prinsip-dioda-

dioda-zenner-dan-

led\&catid=6:elkadasar\&Itemid=7 .

html (Di Akses pada Minggu, 6

Juni 2010 pukul 15.48 WIB)

[5].Anynomous. 2010. Teknik dasar

Generator

http://bos.fkip.uns.ac.id/pub/ono/p

endidikan/materi-

kejuruan/elektro/jaringan-akses-

pelanggan/teknik dasar generator.

pdf (Di Akses pada Selasa, 2

November 2010 pukul 14.01 WIB)

[6]. Anynomous. 2010. Regulator

http://m-

edukasi.net/online/2007/filterdanre

gulator/regulator.html (Di Akses

pada Selasa, 2 November 2010

pukul 14.01 WIB)

[7]. Donnel, Hendri. 2005. Kupas

Tuntas

hardware handphone. Semarang:

Vytoria

[8].LPTII (Lembaga pendidikan

Teknologi Terapan Indonesia).

2006. Panduan Menjadi Teknisi

Handphone. Depok: PT Kawan

Pustakan

[9]. Musa Purnawarman, SKom., MT.

2010. Komponen.

http://p_musa.staff.gunadarma.ac.i

d/Downloads/files/8048/Kompone

n.pdf (Di Akses pada Senin, 14

Juni 2010 pukul 8.28 WIB)
[10].Irianto Antonius, ST., MT. 2010.

$\mathrm{Bab}$

3.

irianto.staff.gunadarma.ac.id/Dow

nloads/files/4631/bab3.pdf

(Diakses pada Rabu, 16 Juni 2010 pukul 08.07)

[11].Syafii, Bobby. 2009. Mengenal

Jenis-Jenis Baterai Ponsel

http://bobbysafii.wordpress.com/2

009/01/18/mengenal-jenis-baterai-

ponsel.html (Diakses pada Selasa,

2 November 2010 pukul 13.20

WIB)

[12].Sunar Prasetyono, Dwi. 2003.

Belajar Sistem Cepat Elektronika.

Jogjakarta: Absolut

[13].Zamidra Zam, Efvy. 2005.

Panduan Praktis Belajar

Elektronika. Surabaya: Indah 